Немеш Олена

доктор психологічних наук, доцент, професор кафедри вікової та педагогічної психології, проректор з науково-педагогічної, навчальної роботи та інформатизації

Рівненського державного гуманітарного університету http://orcid.org/ 0000-0001-8620-3279. DOI https://doi.org/10.35619/prap_rv.vi14.166

\title{
ВПЛИВ МЕДІА НА СОЦІАЛІЗАЦІЮ СУЧАСНОЇ МОЛОДІ
}

Анотація У статті аналізується соціалізуючий вплив сучасних медіа на молодь, його позитивні та негативні наслідки. Розглядається медіаповедінка молоді як система дій особистості в медіапросторі, яка включає різноманітні форми медіаспоживання та медіавиробництва, що зумовлюються ії медіавподобаннями $і$ спрямовуються на задоволення комунікативних, інформаџійних, когнітивних, культурних, рекреаційних та іниих потреб. Визначаються особливості формування особистості сучасної молодої людини як представника «иифрового покоління». Особлива увага приділяється новим медіа, зокрема Інтернету, та тим можливостям, які він надає молоді для задоволення ї̈ потреб. Аналізується феномен інтернетаддикиї, його типи, прояви та ризики. Акиентується роль сім'ї як традииійного інституту соиіалізащії у формуванні медіаповедінки молоді.

Констатується, щуо медіасоиіалізація, з одного боку, є соціалізацією, яка відбувається за активного втручання аудіовізуальних медіа, а з другого - $\epsilon$ вимушеною самосочіалізачією, яка здійснюється в умовах недостатньої участі у житті й соизіалізащії дітей їх соиіалізаційного оточення, передусім близьких $і$ значущих дорослих. Формулюється висновок про необхідність формування медіакультури особистості, щуо визначається як готовність та підготовленість людини до ефективної взаємодії з медіа, як спосіб поводження в інформаційному середовищі, щзо забезпечує мінімізацію ризиків медіавпливу.

Ключові слова: медіа, медіасоиіалізація, кіберсоціалізаџія, медіаповедінка, молодь, інтернет-аддикиія, кібер-буллінг, медіакультура, медіаграмотність.

Постановка проблеми. У сучасних українських умовах становлення інформаційного суспільства виникає низка особливостей перебігу процесу соціалізації усіх верств населення. Це пов'язано зі нестабільною економічною ситуацією, політичними негараздами та військовою агресією на сході України. Нині інформаційний простір стає важливим чинником соціалізації молоді, виникає гостра необхідність дослідження впливу інформатизації на усі сфери життя людини. 3 появою електронних мас-медіа людство, зокрема й молоде покоління, змушене перебувати в особливих умовах існування - в медіасередовищі, що означає розвиток i функціювання людської спільноти, поперше, у світі (у сфері впливу) віртуальних образів (уявної, альтернативної реальності), по-друге - в умовах, коли фактично ігноруються відмінності між дорослими глядачами молодіжною медіа-аудиторією, по-третє - на тлі (у сфері впливу) постійно підвищеної агресії. I все це досить обмежено залежить від особистого вибору глядачів. Отже, виникає i дедалі міцнішає цілком природне припущення, що поява такого потужного соціалізаційного чинника, яким $є$ сучасні мас-медіа, не може не позначитися на соціалізації прийдешніх медіа-поколінь. Внаслідок цього актуальним і своєчасним є привернення уваги до проблематики соціалізації молоді в сучасному медіасередовищі і передусім впливу його на перебіг і якість соціалізаційного процесу.

Аналіз останніх досліджень 3 проблеми. Можливості впливу нових медіа на процес соціалізації особистості досліджують зарубіжні та вітчизняні учені Абраменкова, Бутиріна, Гошовський, Кудашкіна, Мудрик, Гудсі, Данилова, Ліхтенштейн та ін. Медіа простір як феномен досліджували Луман, Маклюен, Бодріяр, Ліпман, Ноель-Нойман, Нардорф, Федоров. Теоретикометодичне обгрунтування феномену медіасоціалізації та кіберсоціалізації представлено в 
дослідженнях Лучинкіної, Музиченко, Плешакова, Обідіної, Уголькова, Тадаєвої, Петрунько, Коломієць, Зінчиної та ін.

Мета статті. Медіапростір активно впливає на ціннісний світ молоді, їі виховання та освіту, формуючи та змінюючи установки, моделі поведінки, діяльності і навчання. Отже, метою статті $є$ визначення місця медіа в житті сучасної молоді та їхньої ролі в соціалізації молодої людини.

Виклад основного матеріалу дослідження. Не применшуючи значущості інших чинників впливу на формування особистості молодої людини, наприклад, батьківської сім'ї, інституту освіти, однолітків, зазначимо, що ми, як і багато інших дослідників, акцентуємо на зростаючій ролі мас-медіа в житті сучасної молодої людини. Розширення числа радіо- й телеканалів, що конкурують між собою, ускладнення жанрово-тематичної структури їхніх програм, велика кількість різноманітної друкованої продукції, розвиток мережі Інтернет створили в останні роки якісно новий медіапростір, до якого людина «підключається» 3 раннього дитинства. Вирішальний вплив медіа на молодіжну свідомість дозволяє номінувати соціалізацію в сучасному інформаційному суспільстві як медіасоціалізацію. Отже, «поняття «соціалізація» сьогодні повинно включати як важливу складову частину адаптацію не тільки до соціальних зв'язків, але і до інформаційних посередників» (Луков,2008). Під медіасоціалізацією розуміють складову процесу соціалізації людини інформаційного суспільства, яка здійснюється через нові медіа та заохочує до соціального досвіду людства кожного індивіда. Поряд із терміном «медіасоціалізація» зустрічається поняття «кіберсоціалізація», яке Петрунько (2007) визначає «як процес якісних змін структури самосвідомості особистості й мотиваційно-потребової сфери індивідуума, що відбувається під впливом і в результаті використання людиною сучасних інформаційнокомунікаційних, цифрових і комп'ютерних технологій у контексті засвоєння і відтворення культури в рамках персональної життєдіяльності»

Кіберсоціалізація стала складовою медіасоціалізації, вона забезпечує соціальний розвиток особистості через інтернет-простір та впливає на якісні зміни структури самосвідомості людини. Соціологічні аспекти кіберсоціалізації обумовлені іiі суперечливістю, яка полягає в тому, що кіберпростір розширює горизонти інтерсуб'єктивності життєвого простору особистості та при цьому приховує в собі серйозні загрози руйнування особистості, культури, не кажучи вже про можливість маніпулювання свідомістю особистості, що призводить до різних залежностей від Інтернету, віртуалізації свідомості тощо. За допомогою Інтернету молодь може брати участь в економічному, культурному, політичному, науковому житті суспільства. Однією, але дуже важливою особливістю кіберсоціалізації молоді, є можливість спілкуватися в Інтернетсередовищі в реальному часі. Але ці інтереси можуть носити як соціально корисний, гуманний, нейтральний характер, так і асоціальний i, навіть, антисоціальний.

Слід зазначити, що в процесі кіберсоціалізації перебудовуються всі без винятку сфери життєдіяльності людини (інформаційна, освітня, дозвіллєва тощо). Крім того, Інтернет-простір істотно впливає на засвоєння соціальних норм, формування ціннісних просоціальних орієнтацій і $€$ апробацією сімейних, громадянських, загальнолюдських форм поведінки. Наголосимо, що сучасні темпи життя людини спрямовані на такі орієнтири, які основані на посиленій ролі сучасного інформаційного способу життя, тобто людину спонукають до того, щоб вона мала постійний доступ до Інтернет-простору для отримання інформації, що вможливлює використання цього простору як засобу неформальної освіти. Особливістю соціалізації людини в цьому віртуальному середовищі $є$ іï активність. Індивід у кіберпросторі перетворюється із соціального об'єкта на соціальний суб’ єкт. Тому, кіберсоціалізація людини як складова медіасоціалізації, з одного боку, $є$ інноваційним феноменом, 3 іншого - уже давно стала фактичною реальністю нашого світу, невід‘ємною частиною соціалізації сучасної особистості, а також двигуном науково-технічного, економічного та соціального прогресу людського суспільства (Тадаєва, 2017).

Телебачення, інтернет та інші нові медіа для юних користувачів 3 технічних засобів комунікації перетворюються на особливе соціальне середовище, яке існує у віртуальній формі. Характеризуючи відносини особистості з медіа, ми використовуємо поняття «медіаповедінка», під якою розуміємо систему дій особистості в медіапросторі, яка включає різноманітні форми медіаспоживання i медіавиробництва, зумовлені іiі медіавподобаннями i спрямовані на 
задоволення комунікативних, інформаційних, когнітивних, культурних, рекреаційних та інших потреб. Групи в соціальних мережах, комп'ютерні ігри, які поступово витісняють традиційні види дозвілля, фільми, музика, почуття і стосунки, весь речовинний, матеріальний світ - все це конструюється молодою людиною 3 фрагментів, що існують у цифровому форматі. В умовах комфортного для молодої людини цифрового простору вона швидко і легко адаптується до нього, приймає його правила існування. При цьому, з одного боку, нові медіа впливають на молодих користувачів, з іншого, медіа самі породжуються «цифровим поколінням» (Жилавська,2007) або, як його ще називають, digitalnatives («цифрові туземці»), digitalnation («цифрова нація»), netgeneration («мережеве покоління»). Так іменують тих, хто був народжений після 1980 р. та дорослішав разом з бурхливим розвитком нових медіа. Зауважимо, що для України цей термін треба змістити ще на десять років, бо до нас новітні технології прийшли з запізненням у порівнянні з західними країнами. Також до переліку домінувань сучасної молоді слід додати термін «покоління Z», або «центеніали», які прийшли на зміну поколінням X та Y згідно популярній теорії поколінь Нила Хоува та Уільяма Штрауса. Це діти, народжені після 1996 або 2000 рр. (за даними різних досліджень).

Американські дослідники Полфрі та Гассер з Беркманського центру з вивчення інтернету і суспільства при Гарвардському університеті змальовують «соціологічний портрет» цифрового покоління і відносить до його суттєвих рис такі, як «тотальна» креативність, інноваційність (відмова від застарілих і традиційних форм діяльності та стосунків); інформованість (завдяки постійній підключеності до інформаційних мереж і пошукової діяльності); «багатозадачність» (здатність вирішувати декілька когнітивних завдань одночасно). Серед «проблемних зон» дослідники визначають інформаційну перевантаженість, інтернет-аддикцію, контакти зі зловмисниками і доступ до небезпечного контенту (Годик, 2011). Американська дослідниця проблем взаємодії людини та технологій Теркл звертає увагу на таку особливість молоді, як «тривога непідключеності», яка може набувати рис паніки. Відомим є експеримент, коли 68 підліткам запропонували на вісім годин відмовитися від усіх гаджетів і зайнятися чим завгодно іншим. До кінця терміну дійшли лише 2 дитини, інші ж визнали, що є залежними від цих речей; у деяких виникли нудота, пітливість, болі в животі, а троє зізналися у суїцидальних думках. Як тільки для них експеримент перервали, вони одразу почали дзвонити друзям, грати в комп'ютерні ігри, користуватися соціальними мережами (Мурашова). Аналогічний експеримент було проведено в університеті штату Меріленд (США): там на 24 години позбавили комп'ютера, мобільних телефонів, планшетів тощо студентів 310 країн світу віком від 17 до 23 років. В результаті кожний п'ятий описав симптоми, подібні до симптомів абстинентного синдрому, по $11 \%$ зізналися у відчутті безпорадності та ізольованості, 19\% розповіли про те, що страждали, $\mathrm{i}$ тільки 21\% визнали користь подібного досвіду (Интернет и телефон вызывают у детей зависимость)

Отже, зрозуміло, що більшість молоді розглядає інтернет як природне середовище проживання, як повітря, яким дихають. Воно може бути чистим, як після дощу, або загазованим i повним шкідливих речовин. Для старшого покоління медіапростір є безнадійно незрозумілим i, 3 огляду на це, якщо не ворожим, то недружнім, бо він не відповідає традиційним уявленням про культурні та духовні цінності, які виробило людство. I в цьому протиріччі закладено багато відповідей на непрості питання взаємин нинішніх поколінь.

Трансформації, що відбуваються в суспільстві під впливом нового медіапростору, призвели до закріплення у свідомості молоді таких цінностей, як право на свободу спілкування i самовираження, на доступ до матеріальних благ і свободу переміщення, право на шанобливе ставлення до своїх потреб, до особистого життя та власного часу. Це нові цінності, народжені новою епохою. I якщо традиційні мас-медіа підкорюються законам суспільства масового споживання і формують уніфікований, примітивний тип особистості, то нові медіа наслідують логіку постмодерну, де кожна людина довільно обирає власний унікальний стиль життя 3 його ідеологією, цінностями та інструментарієм і створює свою індивідуальну реальність.

Нові медіа дозволяють молоді вирішувати актуальні для неї завдання: зв'язки з відкритим світом для зовнішньої і внутрішньої комунікації, для самовираження, яке сьогодні стає однією 3 найважливіших цінностей, для управління власними ресурсами i самоорганізації i, нарешті, для 
реалізації тих прав і свобод, які придбані нею у процесі розвитку суспільства. У молоді, як і у будь-якої іншої соціальної групи, у взаємодії з медіа формується певна медіаповедінка, яка характеризує ії як частину стратифікованої спільноти. Нові медіа надали молодим людям нове середовище і засоби для соціалізації, тут вони не тільки експериментують зі своїм образом, але знаходять друзів, однодумців, вчаться спілкуватися і будувати стосунки. 3 одного боку, це має розвиваюче і терапевтичне значення при становленні особистості, але 3 іншого, стосунки, які будуються в онлайні, де в один-два кліка «мишкою» можна знайти друзів і також легко розлучитися $з$ ними або бути залишеними, не є тотожними реальним. Не завжди усвідомлюють молоді люди і факту публічності інтернету, адже зафіксовані там відомості зберігаються дуже довгий час, їх важко видалити i зробити зовсім недоступними. Інтернет стає творчою лабораторією, в якій молоді користувачі вчаться мистецтву презентації себе зовнішньому світу в просторі, який здається більш безпечним, ніж є насправді. Те, що віртуальний образ так легко створити і зробити загальнодоступним, містить в собі ризик - через можливість маніпуляцій i фальсифікацій.

У XXI ст. змінилася сама природа ідентичності, причому не тільки для юних користувачів, а й для всіх, хто «живе» в мережевих спільнотах. Ідентичність людини, що живе у світі цифрових технологій, - це синтез образів, досвіду самовираження в реальному і віртуальному просторах. Найбільших змін зазнає соціальна ідентичність, яка тепер більше, ніж будь-коли, формується не тільки на основі слів чи дій самої особистості, але й того, що про неї говорять в інтернеті інші. Їхні оцінки та коментарі загальнодоступні, важко контрольовані і керовані (Годик, 2011). Не брати участь в онлайн-комунікації для представника «цифрового покоління» - це ризик опинитися на периферії, втратити друзів, бути виключеним зі спілкування, навіть обмеженим у розвитку певних навичок соціалізації в захоплюючій діяльності зі створення та експериментування 3 власною ідентичністю. Формування особистості сучасної молодої людини відбувається під впливом двох світів: реального та віртуального. У повсякденному житті підлітки самопрезентують себе за допомоги відомих маркерів - одягу, сленгу, причетності до «своїх» спільнот і субкультур.

У віртуальному ж світі вони так само виражаються, але відбувається це засобами цифрових технологій, що надає інтернет-простір. Створення власних сторінок у соціальних мережах, спілкування в них, обмін інформацією, участь у мережевих іграх та співтовариствах гравців - все це сприяє соціалізації особистості підлітка сучасного інформаційного суспільства. Горошко (2010, c.32) зауважує: «3 розвитком i поширенням інтернету він поступово перетворюється на універсальний комунікативний простір, у якому запускаються механізми віртуалізації соціальності, яка $є$ неминучим соціальним ефектом новітніх інформаційно-комунікативних технологій». Наукові праці, присвячені аналізу впливу медіа на особистість, що формується, акцентують увага як на позитивних, так і на негативних наслідках такого впливу. До перших найчастіше відносять такі: інформаційна функція, релаксаційний, рекреаційний ефект, відволікання уваги від повсякденності, розширення життєвого світу людини тощо.

Говорячи про негативні наслідки впливу медіа, зазначимо, що це питання привертає до себе все більшу увагу дослідників. Якщо вивчення впливу телебачення на особистість, що формується, налічує більш ніж півстоліття, то ефекти від занурення в інтернет-простір тільки усвідомлюються спеціалістами. Когнітивна і психічна сфери особистості молодою людини знаходяться у стадії формування, тому вона стає адресатом мало критичним і дуже емоційним. Усі пропоновані медіа змісти - важливі і незначні, забавні і трагічні, поверхневі і глибокі - для підлітка $є$ рівнозначними, він їх не впорядковує і не розподіляє щодо їхньої значущості. У розвитку молодої людини можна виділити характерні для певного віку ознаки сприйняття. Проаналізуємо ці ознаки на прикладі телевізійних передач:

дитина у віці 7-9 років часто сприймає зміст фільму як абсолютну правду, а свої переживання відтворює в іграх та малюнках;

підлітки у віці 10-12 років починають шукати зразки для наслідування, ототожнюють себе з телевізійними героями, приймають їхні цінності, мотиви поведінки;

у підлітків 13-15 років, зростає схильність до оцінювання подій і емоційність переживання; 
(Вєнчковска, 2018).

про свідоме сприйняття телебачення можна говорити лише у віці 16-18 років

Сьогодні, коли медіа стали невід'ємною складовою нашого життя, обговорюється і досліджується феномен залежності від них. Якщо раніше ми могли говорити про своєрідну телеманію, то зараз частіше досліджують інтернет-аддикцію. За симптомами таку залежність можна ставити поряд 3 такими шкідливими звичками, як куріння, вживання алкоголю i наркотичних препаратів. У наукових джерелах інтернет-аддикція визначається як нав'язливе прагнення використовувати інтернет та надлишкове користування ним, неспроможність людини вийти з мережі та постійне бажання потрапити туди. Дослідники називають декілька іiі проявів. Перший 3 них - «цілеспрямоване очікування доступу до віртуального середовища. Потім з'являється стан ейфорії під час перебування у віртуальному просторі, зростає час, проведений перед монітором комп'ютера. Наступні симптоми обмежують соціальну активність індивіда: спершу людина починає ігнорувати членів референтних груп (родичів, найближчих друзів); далі вона почуває себе некомфортно у реальності, поза віртуальним спілкуванням у неї виникає відчуття порожнечі, депресії, роздратованості (своєрідна «ломка»); зрештою, втрачається соціальна активність, наслідком чого може бути розпад сім'ї, проблеми з навчанням чи роботою тощо» (Римашевський, 2007). Фактично віртуальне середовище виглядає навіть більш адекватним, ніж реальний світ, віртуальний образ витісняє реальну особистість.

Можливість перевтілитися в когось, ким ти не є насправді, в «ідеальну особистість» відкриває для молодої людини нові відчуття, адже відомо, що значна частина інтернет-аддиктів обирає саме таки сервіси, які пов'язані з анонімним спілкуванням. Психологи виділяють декілька типів інтернет-аддикції: нав'язливий веб-серфінг, тобто довгі мандри в Інтернеті в пошуках інформації (не завжди корисної і потрібної); пристрасть до віртуального спілкування та віртуальних знайомств; ігрова залежність, захопленість комп'ютерними іграми, в тому числі в мережі; нав'язлива фінансова потреба - гра в азартні ігри в інтернеті, непотрібні покупки в інтернет-магазинах або участь в інтернет-аукціонах; пристрасть до перегляду фільмів через інтернет; кіберсексуальна залежність (Найдьонова, 2012).

Окрім інтернет-аддикції, також говорять про кіберхондрію (людина знаходить у себе симптоми хвороб, про які дізналася з медіа), кіберхворобу (головокружіння, сухість очей, болі у спині та ін.), Facebook-депресію (негативні відчуття від відсутності або надлишковості контактів у соціальній мережі, а також почуття неповноцінності при зіставленні свого життя з віртуальним образом «друзів»), «ефект Google» (людина впевнена, що знання не потрібні, тому що все можна швидко знайти через пошукову систему), номофобію (боязнь залишитися без мобільного телефону), синдром фантомного дзвінка (людині здається, що його телефон дзвонить) (Интернет и телефон вызывают у детей зависимость).

У наукових джерелах виділяють також кілька видів залежності з огляду на те, до чого сформувалася пристрасть у конкретного індивіда. Перший вид - «кіберсекс». Люди, які страждають від нього, відвідують, завантажують чи продають в інтернеті матеріали порнографічного характеру або фантазують про це у рольових, спеціалізованих чатах. Другий вид - залежність від віртуальних знайомств. Сюди відносять молодь, яка активно відвідує різноманітні чати та онлайнові служби знайомств. Наслідки цієї залежності - подружні зради та дестабілізація сімейного життя. Третій вид - онлайнові ігри та аукціони. Значна частина молоді віддає перевагу комп'ютерним іграм 3 віртуальними партнерами чи купівлі-продажу на віртуальній біржі. Вони полюбляють відвідувати віртуальні казино, портали інтерактивних ігор, електронні аукціони чи брокерські контори, витрачаючи значні суми коштів. Ще один вид залежності - інформаційне перевантаження. Велике розмаїття інформації в інтернеті створило особливий тип поведінки, при якому людині просто необхідно постійно переглядати різноманітні інтернет-ресурси у пошуках інформації. Молодь, яка страждає цим видом залежності, проводить багато часу в накопиченні та організації матеріалів різної спрямованості. Нав'язлива потреба у таких пошуках інформації призводить до зниження продуктивності роботи. Будь-який 3 перелічених вище видів залежності від віртуального середовища $є$ однаково небезпечним i свідчить про відхилення від норми (Римашевський, 2007).

Випуск 14, 2020 Збірник наукових праць РДГУ. 
Хоча інтернет-аддикцію доки не вважають психічним захворюванням, окремі країни занепокоєні нею, адже за даними різних джерел, до 10\% користувачів мережі страждають на неї. Так, у Фінляндії юнакам з інтернет-залежністю надають відстрочку від служби в армії, а Китай ще 2008 року заявив про те, що буде лікувати від цієї хворобливої пристрасті. Правда, є думка, що проблема інтернет-залежності дещо надумана чи перебільшена, мовляв, будьяке нове явище завжди викликає у певної частини людей побоювання, а інша частина фанатично їм захоплюється. «Кількість інтернет-аддиктів не більша, ніж «макдональз-залежних», але від Інтернету користі все ж більше», - вважають прибічники такої думки. Спеціального аналізу заслуговує і такий феномен сучасного інтернет-простору, як кібер-буллінг - це напади з метою завдання психологічної шкоди, які здійснюються через електронну пошту, сервіси миттєвих повідомлень, у чатах, соціальних мережах, на web-сайтах, a також за допомогою мобільного зв’язку (Найдьонова). Така багаторазово повторювана агресивна поведінка має на меті зашкодити людині і базується на дисбалансі влади (фізичної сили, соціального статусу в групі). Як правило, саме підлітки найчастіше стають як об’ єктами буллінгу, так і ініціаторами його. Відома жорстокість, притаманна саме підлітковому віку, сьогодні набуває нових форм, відповідних сучасним реаліям. Кібербуллінг включає низку форм поведінки (від жартів, що не сприймаються всерйоз, до психологічного віртуального терору), яка завдає непоправної шкоди, призводить до суїцидів $\mathrm{i}$ смерті. $€$ навіть поняття булліциду - загибелі жертви внаслідок буллінгу.

Американські дослідники виділили вісім основних типів буллінгу (Найдьонова,2018):

1. Перепалки - обмін короткими запальними репліками між двома та більше людьми, що розгортається зазвичай у публічних місцях глобальної мережі (форуми, чати, обговорення постів чи світлин). Можуть перетворюватися на затяжний конфлікт.

2. Нападки, постійні виснажливі атаки - повторювані образливі повідомлення, спрямовані на жертву (наприклад, sms-повідомлення, постійні дзвінки); трапляються також у чатах, форумах, навіть в онлайн-іграх.

3. Наклепи - поширення принизливої неправдивої інформації. Текстові повідомлення, фото, пісні, які часто мають сексуальний характер.

4. Самозванство, втілення в певну особу - переслідувач позиціонує себе як жертву, використовуючи iii пароль доступу до аккаунту в соціальних мережах, у блозі, пошті, системі миттєвих повідомлень, або ж створює «клон»-аккаунт із аналогічним нікнеймом та здійснює від імені жертви негативну комунікацію.

5. Ошуканство, видурювання конфіденційної інформації та ії розповсюдження - отримання персональної інформації і публікація її в інтернеті або передача тим, кому вона не призначалася.

6. Відчуження. Будь-якій людині притаманне бажання бути включеною в групу. Виключення ж із групи сприймається як соціальна смерть. Що більшою мірою людина виключається із взаємодії, то гірше вона почувається й то більше падає іï самооцінка. У віртуальному середовищі це може призвести до повного емоційного руйнування особистості.

7. Кіберпереслідування - приховане вистежування жертви 3 метою організації нападу, побиття, згвалтування тощо.

8. Хепіслепінг - назва походить від випадків в англійському метро, де підлітки ляскали перехожих, тоді як інші записували це на камеру мобільного телефону. Зараз ця назва закріпилася за будь-якими відеороликами із записами реальних сцен насильства. Ці ролики розміщують в інтернеті, де їх можуть передивлятися тисячі людей без згоди жертви.

Таким чином, інтернет-простір, комп’ютерні мережі здатні впливати на формування негативних психологічних установок у молоді. Безумовно, в сучасних умовах неможливо (та й неправильно) повністю ізолювати молоду людину від використання ресурсів інтернету. Однак повинні існувати дієві способи нейтралізації негативного інформаційного впливу комп'ютерних мереж. Особливу роль у цьому процесі повинні відігравати традиційні інститути соціалізації особистості, перш за все сім'я і освіта. Зацікавлена участь дорослих, здатних об'єктивно оцінити ресурси, якими послуговується їхня дитина, і здійснити їхню фільтрацію, дозволить правильно зорієнтувати молоду людину в інформаційних потоках Основи медіаповедінки підлітка все ж таки закладаються в родині. Це досліджували, наприклад, німецькі соціологи (Зандер, 2007). Від медіабіографії покоління батьків, особистих преференцій, стилю комунікації, а також від 
концепції виховання і поглядів кожного члена родини на медіа залежить тип медіаповедінки особистості, що формується.

«Сімейний клімат» і комунікаційний стиль сім'ї накладають відбиток на ставлення до масмедіа. Батьки своєю поведінкою і стилем виховання можуть створити для дітей рамки, які допомогли б їм здобути власний досвід у ставленні до медіа. Важливо, яке ставлення до суті медіа виказують батьки, наприклад, схвалення, заперечення, підтвердження, відхиляння, емоційне чи раціональне, позитивне чи негативне підсилення. Від батьків діти отримують концептуальні знання та дії щодо мас-медіа.

Дослідження з теми «Родина і мас-медіа» показують:

- оцоціальна й медійна поведінка у родині тісно пов’язані між собою;

- що медійна поведінка $\epsilon$ складовою частиною повсякденного досвіду та світоглядного спрямування;

що в загальному контексті родини значення медіа змінюється для її окремих членів або ж вони взаємно впливають одне на одного;

що значення медіа залежить від того, в яких життєвих умовах перебуває та чи інша сім'я (прошарок, доходи, рівень освіти, місце проживання, розмір помешкання, форма сім'ї) (Зандер, 2007).

Не повинна залишатися осторонь від розглянутої проблеми і держава. Назріла необхідність визначення твердих критеріїв допущенності розміщення в мережах певних видів інформації. Варто виробити дієві механізми обмеження доступу різних вікових категорій користувачів інтернету до окремих сайтів. Потрібно законодавчо закріпити відповідальність власників сайтів за зміст розташованих інформаційних матеріалів. Зрештою, необхідно пам'ятати, що для того, аби повернутися до реального світу, реальних друзів, до самих себе, достатньо просто вимкнути комп'ютер.

Результати соціологічного дослідження «Життєвий світ підлітків Рівненщини» проведені в 2017 р. (об’єкт дослідження - учні 7, 9 і 11 класів середніх навчальних закладів; за репрезентативною виборкою опитано 950 школярів Рівного підтверджують значущу роль нових медіа в житті молоді. Комп'ютер для сучасної дитини - не невідомий технічний пристрій, а цілком знайомий і постійно використовуваний агрегат. За даними зазначеного дослідження, $95 \%$ опитаних мають його вдома, а 98\% заявили, що вміють ним користуватися, 95 \% респондентів зареєстровано в соціальних мережах, а найбільш популярними цілями користування інтернетом $\epsilon$ спілкування та прагматичні навчальні практики. Якщо враховувати розповсюдження «карманних» девайсів (смартфонів, планшетів тощо), то стає зрозумілим, що практично завжди дитина має можливість користуватися перевагами «нових медіа», а контроль з боку батьків за тим, як саме використовує дитина цифрові технології, стає вкрай ускладненим. Перегляд телевізійних програм як дозвільна практика, за даними порівняльного аналізу результатів досліджень жителів м.Рівне 1998 р. та 2017 р., став менш розповсюдженим видом медіаповедінки: якщо за результатами дослідження у 1998 p. ${ }^{1} 74$ \% школярів щоденно дивились телевізор, то дослідження 2017 p. продемонструвало зниження долі таких підлітків до 35\%. Загалом же і перегляд телебачення, i спілкування в соціальних мережах посідають 2-3 рангове місце в структурі дозвілля, поступаючись прослуховуванню музичних записів (що, у свою чергу, є складовою медіаповедінки, адже для отримання, зберігання, розповсюдження та прослуховування музики використовується весь арсенал медіагаджетів - від телефонів до комп’ютерів).

Дослідження 2017 р. року зафіксувало помітну трансформацію структури вільного часу підлітків. Найбільш розповсюдженими заняттями у вільний час серед опитаних нами підлітків $\epsilon$ прослуховування музичних записів, спілкування у соціальних мережах, просто відпочинок, зустрічі з друзями, перегляд телевізійних передач, комп’ютерні ігри. Підкреслимо, що саме ці

$1^{1}$ За репрезентативною вибіркою було опитано 1200 підлітків віком від 12 до 17 років, що мешкають у м. Рівне. 
дозвільні практики утворюють типовий для цієї соціокультурної спільноти стиль життя. Порівняно з аналогічним дослідженням 1997 р., коли перегляд телебачення займав перше місце серед видів дозвільної діяльності, ми спостерігаємо його витіснення різними видами інтернетпрактик.

Таким чином, сучасні підлітки - це перше покоління, яке народилося в епоху Інтернету. Вони не пам'ятають, яким було життя без гаджетів, i проводять зі смартфонами і планшетами більше восьми годин на день. Цифровими додатками вони користуються так само природно, як дихають. Покоління $\mathrm{Z}$ не ділить світ на цифровий і реальний, їх життя плавно перетікає на екран $\mathrm{i}$ назад. Принципіальна властивість нового покоління полягає в тому, що у нього в крові високі технології, з якими воно поводиться на зовсім іншому рівні, ніж навіть представники попередніх поколінь. Це покоління народилося в епоху постмодернізму і глобалізації і виросло в світі, в якому можливості просто безмежні, а ось часу на все не вистачає. Саме тому його представники адаптувалися до необхідності дуже швидко оцінювати і просівати величезні обсяги інформації. Суспільство схильне або критикувати молодість за те, що вона щось робить інакше, або романтизувати ii. Однак насправді «цифрове покоління», або покоління (Z) знаходиться десь посередині. Його представники стикаються 3 проблемами, що виникають на певному життєвому етапі у всіх: розставанням з батьками, початком кар'єри, формуванням особистої ідентичності. Однак їм доводиться робити це в стрімку технологічну епоху. Незважаючи на таку обізнаність молоді щодо сучасних медіа, ризики і загрози віртуального світу актуалізують так звану «хибну соціалізацію» (за Штомпкою). Тому дуже важливо не залишати молоду людину сам на сам 3 цим світом, а цілеспрямовано впливати на формування у підлітка медіакультури, адекватної викликам часу. Формування медіакультури особистості як певний результат іiі медіасоціалізації $\epsilon$ актуальним та затребуваним в умовах інформаційно насиченого суспільства з відкритим доступом до будь-якої медійної інформації в глобальному віртуальному просторі. При цьому під медіакультурою на особистісному рівні ми розуміємо здатність людини ефективно взаємодіяти 3 мас-медіа, адекватно поводитися в інформаційному середовищі (Коновалова,2004). Близьким до нашого тлумачення медіакультури є таке: «Медіакультура особистості - це діалоговий спосіб взаємодії з інформаційним суспільством, який включає ціннісний, технологічний та особистіснотворчій компоненти та призводить до розвитку суб’єктів взаємодії» ( с. 9).

Характеристиками медіакультури, які розкривають ії сутність, $є$ :

«медіаобізнаність» - характеристика медіакультури, яка відображає ступінь засвоєння особистістю системи знань про засоби масової комунікації, їхню історію та особливості функціонування, користь i шкоду для людини, уміння убезпечити себе від негативних інформаційних впливів і вільно орієнтуватись у світі інформації;

«медіаграмотність» - характеристика медіакультури, яка стосується вміння користуватися інформаційно-комунікативною технікою, виражати себе і спілкуватися за допомоги медіазасобів, свідомо сприймати і критично тлумачити інформацію, відділяти реальність від іiі віртуальної симуляції, тобто розуміти реальність, сконструйовану медіаджерелами, осмислювати владні стосунки, міфи і типи контролю, які вони культивують;

«медіакомпетентність» - складова медіакультури, що забезпечує розуміння особистістю соціокультурного, економічного і політичного контексту функціонування медіа, засвідчує їі здатність бути носієм і транслятором медіакультурних смаків і стандартів, ефективно взаємодіяти з медіапростором, створювати нові елементи медіакультури сучасного суспільства [9].

Висновки i перспективи подальших розвідок. Підсумовуючи зазначене вище, підкреслимо, що для попередження ризиків медіасоціалізації, підвищення соціальної та психологічної безпеки підлітків у медіапросторі, для успішного формування медіакультури особистості необхідними $є$ такі кроки. Перш за все усвідомлення та обговорення проблеми медіасоціалізації сучасної молоді. По-друге, прийняття на себе відповідальності всіма членами інтернетспільноти: як творцями сервісів і розробників програмних продуктів, так і простими користувачами. По-третє, формування у молодих українців медіакультури, яке б відбувалося на рівні традиційних соціалізаційних інститутів, перш за все сім’ї та освіти. В нашій країні прийнято «Концепції впровадження медіаосвіти в Україні», яку було прийнято ще у 2010 р., передбачено 
«забезпечення всебічної підготовки дітей і молоді до безпечної та ефективної взаємодії із сучасною системою медіа, формування у них медіаобізнаності, медіаграмотності i медіакомпетентності відповідно до їхніх вікових та індивідуальних особливостей» (Найдьонова, 2012) Важливою умовою повноцінної реалізації цієї концепції, в першу чергу, $\epsilon$ впровадження відповідних курсів в середніх навчальних закладах. Будемо сподіватися, що майбутня аудиторія медіа, основу якої складає сучасна молодь, все більше буде набувати статусу повноцінного співучасника і партнера в комунікаційному процесі. У такому випадку можна буде говорити про культуру комунікації як уміння усвідомлено сприймати, критично осмислювати, інтерпретувати медіатексти 3 метою розширення загальних, соціокультурних та професійно значущих знань, комунікативних та творчих здібностей.

\section{СПИСОК ВИКОРИСТАНИХ ДЖЕРЕЛ:}

1. Вєнчковска, М. (2018) Дитина в світі мас-медіа. Що втягує твою дитину? Взято $з$ ftp.honoratki.nazwa.pl>uaa/MasMedia...Mas-Media5.pdf.

2. Годик, Ю. О. (2011)Угрозы и риски безопасности детской и подростковой аудитории новых медиа. Взято з http://www.mediascope.ru/node/841.

3. Горошко, О. I. (2010) Гендерні аспекти Інтернет-комунікаџій: (Автореф. дис. на здобуття наук. ступеня докт. соціолог. наук). Харків.

4. Жилавская, И. В. (2007, 20-21 ноября) . Информационные медиа. «Медиаобразование: от теории - к практике» : сборник материалов Всероссийской научно-практической конференции «Медиаобразование в развитии науки, культуры, образования и средств массовой информации». Томск: НОУ ВПО ТИИТ. Серия «Библиотека САМО».

5. Зандер, Е.(2007) Медіа в юнацькому віці. Взято з http://www.ji.lviv.ua/n46texts/sander.htm.

6. Зінчина, О. (2017) Медіасочіалізація сучасної молоді: виклики $i$ відповіді. Взято 3 https://periodicals.karazin.ua/ssms/article/view/10283

7. Интернет и телефон вызывают у детей зависимость. Взято из http://ivona.bigmir.net/deti/schoolboy/309819-Internet-i-telefonvyzyvajut-u-detej-zavisimost.

8. Коновалова, Н.А. (2004). Развитие медиакультуры студентов педагогического вуза. (автореф. дисс. на соискание учен. степени кандидата пед. наук). Вологда.

9. Концепиія впровадження медіа-освіти в Украӥні. Взято з http://h.ua/story/294365

10. Луков, А. В. (2008). Социология телевидения: становление научной дисциплины. Информационный гуманитарный портал «Знание. Понимание. Умение»- Социология. №3. Взято из http://www.zpu-journal.ru/e-zpu/2008/3/Lukov_AV2/;

11. Лук'янчук, С.В.(2019) Медіасочіалізація та кіберсоціалізаџія як складові формування особистості. Взято 3 https://natc.org.ua/docs/Conferencia/2019/Conferencia_mat_20191205. pdf\#page $=124$

12. Мироненко, Г. (2007). Часові профілі «залежних» та «вільних» споживачів телевізійної продукції. Соціальна психологія. 2 (22). 168-175.

13. Мурашова, К.(2012) Кого боятся подростки. Взято из https://snob.ru/selected/entry/45522.

14. Найдьонова, Л. (2018) Кібер-буллінт: небезпечне віртуальне «бикування». Взято 3 http://old.mediasapiens.ua/material/1152.

15. Найдьонова, Л.А., Іванов, В. Ф., Волошенюк, О. В., Дзюба, Д. Ю. та ін. (2012). Вплив медіа на розвиток особистості. Медіаосвіта та медіаграмотність: підручник. - Київ: Центр вільної преси.

16. Петрунько, О.В. (2007) Соціалізація в умовах медіа середовища: актуальність проблеми. Взято з http://ap.uu.edu.ua/article/260

17. Петрунько, О. В. (2010) Соціалізація дитини в агресивному медіасередовищі. (Автореф. дис. д. психол. наук). Інститут соц. та політ. психології НАПН України. Київ.

18. Римашевський, Ю. Віртуалізація молоді як соціально-психологічний феномен сучасності. Взято з http://www.ji.lviv.ua/n46texts/rymashevskyj.htm

19. Тадаєва, А.В. (2017) Кіберсоиіалізаџія як складова соиіалізаџії дітей молодшого шкільного віку в умовах інформащійного суспільства. Взято 
http://www.ic.ac.kharkov.ua/nauk_rob/nauk_vid /rio_old_2017/vh/v42/32.pdf

20. Facebook-депрессия и эффект Google. (2013) Восемь новых психических недугов из-за Интернета и гаджетов. Взято 3 http://korrespondent.net/lifestyle/health/1615998-facebookdepressiya-i-effekt-google-vosem-novyh-psihicheskih-nedugoviz-za-interneta-i-gadzhetov

\section{REFERENCES:}

1. Vyenchkovska, M.(2018) Dytyna v sviti mas-media. Shho vtyaguye tvoyu dytynu? Vzyato z ftp.honoratki.nazwa.pl>uaa/MasMedia...Mas-Media5.pdf.

2. Godik, Ju. O.(2011) Ugrozy i riski bezopasnosti detskoj i podrostkovoj auditorii novyh media. Vzjato z http://www.mediascope.ru/node/841.

3. Horoshko O. I. (2010) Henderni aspekty Internet-komunikatsii.: (Avtoref. dys. na zdobuttia nauk. stupenia dokt. sotsioloh. nauk). Kharkiv.

4. Zhilavskaja I. V. (2007, 20-21 nojabrja). .Informacionnye media. «Mediaobrazovanie: ot teorii - $\mathrm{k}$ praktike» : sbornik materialov Vserossijskoj nauchno-prakticheskoj konferencii «Mediaobrazovanie v razvitii nauki, kul'tury, obrazovanija i sredstv massovoj informacii». Tomsk: NOU VPO TIIT. Serija «Biblioteka SAMO».

5. Zander, E. (2007) Media v yunatskomu vitsi. Vziato z http://www.ji.lviv.ua/n46texts/sander.htm.

6. Zinchyna, O. (2017) Mediasotsializatsiia suchasnoi molodi: vyklyky i vidpovidi. Vziato z https://periodicals.karazin.ua/ssms/article/view/10283

7. Internet i telefon vyzyvajut $\mathrm{u}$ detej zavisimost'.(2011) Vzjato iz http://ivona.bigmir. net/deti/schoolboy/309819-Internet-i-telefonvyzyvajut-u-detej-zavisimost.

8. Konovalova, N.A. (2004). Razvitie mediakul'tury studentov pedagogicheskogo vuza. (avtoref. diss. na soiskanie uchen. stepeni kandidata ped. nauk). Vologda.

9. Kontseptsiia vprovadzhennia media-osvity V Ukraini. (2016) Vziato z http://h.ua/story/294365

10. Lukov, A. V. (2008). Sociologija televidenija: stanovlenie nauchnoj discipliny. Informacionnyj gumanitarnyj portal «Znanie. Ponimanie. Umenie» - Sociologija. №3. Vzjato iz http://www.zpu-journal.ru/e-zpu/2008/3/Lukov_AV2/

11. Lukianchuk, S.V.(2019) Mediasotsializatsiia ta kibersotsializatsiia yak skladovi $\begin{array}{llll}\text { formuvannia } \quad \text { osobystosti. } & \text { Vziato } & \mathrm{z}\end{array}$ https://natc.org.ua/docs/Conferencia/2019/Conferencia_mat_20191205.pdf\#page=124

12. Myronenko, H. (2007). Chasovi profili «zalezhnykh» ta «vilnykh» spozhyvachiv televiziinoi produktsii. Sotsialna psykholohiia. № 2 (22). 168-175.

13. Murashova, K. (2012) Kogo bojatsja podrostki. Vzjato iz https://snob.ru/selected/entry/45522.

14. Naidonova, L.(2018) Kiber-bulling: nebezpechne virtualne «bykuvannia». Vziato z http://old.mediasapiens.ua/material/1152.

15. Naidonova L.A., V. F. Ivanov, O. V. Volosheniuk, D. Yu. Dziuba ta in. (2012). Vplyv media na rozvytok osobystosti. Mediaosvita ta mediahramotnist: pidruchnyk. - Kyiv: Tsentr vilnoi presy.

16. Petrunko, O.V.(2007) Sotsializatsiia v umovakh media seredovyshcha: aktualnist problemy. Vziato z http://ap.uu.edu.ua/article/260

17. Petrunko, O. V. (2010) Sotsializatsiia dytyny v ahresyvnomu mediaseredovyshchi. (avtoref. dys. dok. psykhol. nauk). Instytut sots. ta polit. psykholohii NAPN Ukrainy. Kyiv.

18. Rymashevskyi, Yu.(2017) Virtualizatsiia molodi yak sotsialno-psykholohichnyi fenomen suchasnosti. Vziato z http://www.ji.lviv.ua/n46texts/rymashevskyj.htm

19. Tadaieva, A.V. (2017) Kibersotsializatsiia yak skladova sotsializatsii ditei molodshoho shkilnoho viku $\mathrm{V}$ umovakh informatsiinoho suspilstva. $\quad$ Vziato $\mathrm{Z}$ http://www.ic.ac.kharkov.ua/nauk_rob/nauk_vid/rio_old_2017/vh/v42/32.pdf

20. Facebook-depressija i jeffekt Google.(2013) Vosem' novyh psihicheskih nedugov iz-za Interneta i gadzhetov. Vzjato z http://korrespondent.net/lifestyle/health/1615998-facebook-depressiya-ieffekt-google-vosem-novyh-psihicheskih-nedugoviz-za-interneta-i-gadzhetov 
THE IMPACT OF THE MEDIA ON THE SOCIALIZATION OF MODERN YOUTH

Olena Nemesh

Doctor of psychological sciences, Professor of the Department age and pedagogical psychology,

Vice-rector for scientific and pedagogical, educational work and information

Rivne State Humanities University http://orcid.org/ 0000-0001-8620-3279

DOI https://doi.org/10.35619/prap_rv.vi14.166

\begin{abstract}
The article deals with the socializing influence of modern media on young people in the conditions of the media society, its positive and negative consequences. Media space actively influences the axiological world of young people, its education and education, forming and changing settings, behavioral, activity and learning patterns.The media behavior of youth has been considered as the system of personality actions in the media space, which includes various forms of media consumption and media production determined by young people's media preferences and aimed at satisfying communicative, informational, cognitive, cultural, recreational and other needs. The peculiarities of the formation of a young person's personality of the modern "digital generation" under the dual influence of the real and virtual worlds have been studied. Particular attention has been paid to the new media, in particular the Internet and the opportunities it provides to young people to meet their needs. The phenomenon of Internet addiction, its types, manifestations and risks have been analyzed. The attention has also been paid to the role of the family as a traditional institution of socialization in shaping the media behavior of young people. It is stated that media socialization, on the one hand, is a socialization that occurs through the active interference of audiovisual media, and on the other - is a forced self-socialization, which is carried out in conditions of insufficient participation in life and socialization of children of their socializing environment, especially close and significant adults. The conclusion has been made on the necessity of forming a media culture of a person as a person's ability to effectively interact with the media, to adequately behave in the information environment as the way of minimizing the risks of media influence.
\end{abstract}

Key words: media, media socialization, cyber socialization, media behavior, youth, Internet addiction, cyber bullying, media culture, media literacy. 